\title{
The effects of steroids in traumatic thoracolumbar junction patients on neurological outcome
}

\author{
Mustafa Kemal İlik, M.D., ${ }^{1}$ Fatih Keskin, M.D., ${ }^{2} \odot$ Fatih Erdi, M.D., ${ }^{2}$ \\ Bülent Kaya, M.D., ${ }^{2}$ ๑ Yaşar Karataş, M.D., ${ }^{2}$ ¿ Erdal Kalkan, M.D. ${ }^{2}$ \\ ${ }^{1}$ Department of Neurosurgery, Farabi Hospital, Konya-Turkey \\ ${ }^{2}$ Department of Neurosurgery, Necmettin Erbakan University Meram Faculty of Medicine, Konya-Turkey
}

\begin{abstract}
BACKGROUND: In this study, we aim to evaluate the potential effects of methylprednisolone on the neurological outcome of spinal cord injury $(\mathrm{SCl})$ patients with thoracolumbar junction (TIO-LI) spine fractures.

METHODS: The data from $182 \mathrm{SCl}$ patients who sustained a thoracolumbar junction spine fracture were operated by us between September 2008 to January 2015 were analysed retrospectively. The patients were divided into two groups: Group I underwent methylprednisolone treatment in conjunction with early surgical intervention, while group 2 underwent only early surgical intervention without methylprednisolone treatment. American Spinal Injury Association (ASIA) motor index scores of the patients were evaluated and compared with statistical methods at admission and at the first-year follow-up.
\end{abstract}

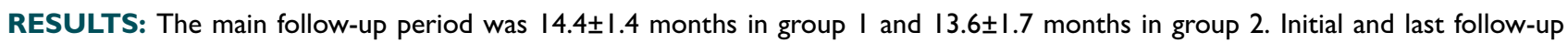
ASIA scores of the patients were similar between groups ( $p>0.05)$, but the complication rate was significantly high in group I $(p<0.05)$.

CONCLUSION: The findings showed that steroids have no significant beneficial effects on the neurological outcome but have significant side effects and leads to increased complication rate in $\mathrm{SCl}$ patients.

Keywords: Methylprednisolone; spinal cord injury; thoracolumbar junction; treatment.

\section{INTRODUCTION}

Although spinal cord injury $(\mathrm{SCl})$ is a serious and common health problem, the effective management of these types of injuries remains controversial. Mechanical compression, impact and shear injuries cause a primary $\mathrm{SCl}$ which initiates a cascade of deleterious pathological processes and leads to secondary neurological tissue destruction. Both primary and secondary injury mechanisms give rise to subsequent neurological deterioration. ${ }^{[1]}$ Surgical procedures, such as decompression and stabilization of the spine, are primarily intended to prevent increased pressure within the spinal canal and to restore normal spinal alignment. Although decompression of the spinal cord is fundamental, it may not prevent the spinal cord from secondary injury. ${ }^{[1]}$
The prevention and treatment of secondary spinal injury remain controversial in spite of several experimental and clinical studies. ${ }^{[2-6]}$

Currently, steroid treatment after $\mathrm{SCl}$ remains a viable option although some studies reported that steroids might not be beneficial and actually increase the overall rate of complications and even may bring about death. ${ }^{[7-10]}$

The primary aim of the present study is to evaluate the potential effects of intravenous methylprednisolone treatment on the neurological outcome of SCl patients which have thoracolumbar junction spine fractures.

Cite this article as: İlik MK, Keskin F, Erdi F, Kaya B, Karataş Y, Kalkan E. The effects of steroids in traumatic thoracolumbar junction patients on neurological outcome. Ulus Travma Acil Cerrahi Derg 2019;25:484-488.

Address for correspondence: Mustafa Kemal ilik, M.D.

Farabi Hastanesi, Nöroşirürji Bölümü, Kosova Mah., Veysel Karani Cad., Ebru Sok., No: 14, Konya, Turkey

Tel: +90 332 - 221 4444 E-mail: mkilik@gmail.com

Ulus Travma Acil Cerrahi Derg 2019;25(5):484-488 DOI: 10.5505/tjtes.2018.8672I Submitted: 19.03.2017 Accepted: 05.12.2018 Online: 05.08.2019

Copyright 2019 Turkish Association of Trauma and Emergency Surgery 


\section{MATERIALS AND METHODS}

The medical records and patient charts of our $182 \mathrm{SCl}$ patients who were sustained an injury at the thoracolumbar junction (TIO-LI) between September 2008 and January 2015 were analyzed retrospectively. All of these patients were isolated $\mathrm{SCl}$ patients who were operated by us within 24 hours after the development of traumatic $\mathrm{SCl}$. The patients who had additional injuries, such as head trauma, thorax trauma, visceral organ injury, or an unstable clinical-biochemical profile, were excluded from the study group in this research.

In our clinic, we routinely started methylprednisolone treatment to $\mathrm{SCl}$ patients according to the NASCIS II protoco ${ }^{[2]}$ until 20II, but then we gave up this medication after novel findings that indicated severe side effects of methylprednisolone treatment. ${ }^{[1]}$

The patients divided into two groups: In group I, there were 95 patients (60 male and 35 female) who received methylprednisolone treatment in conjunction with early surgical intervention. In group 2, there were 87 patients (56 male, 3I female) who underwent only early surgical intervention without methylprednisolone treatment. All patients in this study were admitted to our clinic within eight hours after the development of traumatic $\mathrm{SCl}$.

The methylprednisolone treatment was administered to group I patients according to the NASCIS II protocol. ${ }^{[2]}$ Briefly, methylprednisolone was intravenously administered in a bolus dose $(30 \mathrm{mg} / \mathrm{kg})$ and then in maintenance dose was administered as $(5.4 \mathrm{mg} / \mathrm{kg} / \mathrm{h})$ over 23 hours.

All patients were operated by the same experienced spinal surgery team and underwent rehabilitation at the same physical medicine and rehabilitation center.

All patients underwent a neurological examination during their admission at our emergency service, and their neurological status was categorized into classes $A-D$ according to the criteria established by the American Spinal Injury Association (ASIA) motor index score. Patients with an ASIA motor index score of $E$ were excluded from this study.

All patients were re-evaluated at the last follow-up and their initial and the last follow-up ASIA scores were compared.

Demographic data, initial and the last follow-up ASIA scores, performed surgical procedures were summarized in Table I.

\section{Surgical Treatment}

We aimed to maintain the stability and decompression of the spinal cord in a standard manner in all patients. Eightyeight patients in group I operated with a posterior approach, four patients operated with an anterior approach, and three patient from group I operated by a combined posterior/anterior approach. Eighty-two patient from group 2 operated with a posterior approach, two patient from group 2 operated with an anterior approach, and three patients operated with a combined posterior/anterior approach. The decom-

Table I. Demographic data of the patients, initial and first year follow-up ASIA scores and surgical methods

\begin{tabular}{lcc}
\hline & Group I & Group II \\
\hline Mean age (years) & $38.2 \pm 9.4$ (mean) & $36.6 \pm 8.3$ (mean) \\
Gender & $21-62$ (ranging) & $18-60$ (ranging) \\
Initial ASIA scores & 60 male (63\%) & 56 male (65\%) \\
& 35 female (37\%) & 3 I female (35\%) \\
& 28 ASIA A & 26 ASIA A \\
Last follow-up ASIA scores & 36 ASIA B & 33 ASIA B \\
& 20 ASIA C & I8 ASIA C \\
& I IASIA D & I0 ASIA D \\
Surgical methods & 22 ASIA A & 20 ASIA A \\
& 32 ASIA B & 29 ASIA B \\
& 20 ASIA C & I7 ASIA C \\
& I3 ASIA D & II ASIA D \\
& 8 ASIA E & I0 ASIA E
\end{tabular}

ASIA: American spinal injury association motor index score. 
pression and fusion procedures were conducted in a standard manner for all patients.

Spinal decompression was achieved via discectomy, corpectomy, osteotomy and total laminectomy. Transpedicular screws and cages were used in conjunction with autografts and allografts to establish stabilization and fusion. In group I, eight dural tears occurred during surgery, which were repaired by primary saturation with fibrin glue. In group 2 , the dural tear occurred in seven patients, which were repaired as group $\mathrm{I}$.

After surgery, all patients were fitted with a thoracolumbar brace for eight weeks and referred to the same rehabilitation center within the shortest time interval. All patients in this study underwent rehabilitation at the same physical medicine and rehabilitation center according to their neurological status.

At the last follow-up, all patients were re-evaluated, and their neurological status was assessed according to ASIA classification.

During the follow-up period, some complications, such as decubitus ulcers, deep vein thrombosis, urinary tract infections, were developed in both groups. Encountered complications were summarized in Table 2.

The patients with decubitus ulcers were consulted with plastic reconstructive surgery and after adequate treatment, their decubitus ulcers resolved. Deep vein thrombosis, gastrointestinal bleeding, and uriner tract infection were treated with medical treatment.

Table 2. Prevalence and rate of complications in these series

\begin{tabular}{lcc}
\hline Complications & $\begin{array}{c}\text { Group I } \\
(\mathbf{n}=\mathbf{2 4 , 2 5 \% )}\end{array}$ & $\begin{array}{c}\text { Group 2 } \\
(\mathbf{n}=5, \mathbf{6 \%})\end{array}$ \\
\hline Decubitus ulcers & 6 & 2 \\
Deep vein thrombosis & 5 & 1 \\
Uriner tract infection & 10 & 2 \\
Gastrointestinal bleeding & 3 & \\
\hline
\end{tabular}

Mortality did not occur in these series.

\section{Statistical Analysis}

Statistical analysis was performed using Independent Sample t-Tests and Paired Sample t-Tests with SPSS 18.0 for Windows. A p-value $<0.05$ was considered to indicate statistical significance.

\section{RESULTS}

In this study, two groups of the patients were comparable in terms of the number, age and sex. The mean time interval between the trauma and operation was not statistically significant $(p<0.05)$ among the groups and $14.6 \pm 4.3$ hours in group $I$ and $13.3 \pm 3.5$ hours in group 2 .

ASIA scores of the patients were similar between groups at admission and the one- year follow-up examination without any significant statistically difference $(p>0.05)$.

Mean complication rate was statistically significantly high in group I who underwent steroid treatment after surgery $(p=0.01)$.

The results obtained in this study were summarized in Table 3.

\section{DISCUSSION}

$\mathrm{SCl}$ is a severe public health problem. Neuronal injury occurs via primary and secondary injury mechanisms during $\mathrm{SCl} \cdot{ }^{[12,13]}$

Primary injuries that arise from compression, impact, and shear initiate secondary processes that result in damage characterized by inflammation, ischemia, edema, electrolyte disturbances, free oxygen radicals, apoptosis, and demyelination. ${ }^{[12-16]}$

Primary injury tends to be unavoidable following a trauma, but if the secondary injuries can be blocked or mitigated, then, the neurological function may be spared or treated. ${ }^{[16]}$

Various experimental pharmacological agents have been used over the past 30 years to prevent secondary injury in various animal studies but, of these agents, only methylprednisolone has been widely used in daily clinical practice. ${ }^{[3-5,17-19]}$ Exper-

Table 3. Neurological state initial and the last follow-up in both groups

\begin{tabular}{llcc}
\hline Changes in ASIA scores & Improvement (\%) & Unchanged (n) & Total (n) \\
\hline Group I & ASIA A-B $(n=4)$ ASIA A-C $(n=2)$ ASIA B-C $(n=6)$ ASIA B-D $(n=2)$ & & 68 \\
& ASIA C-D $(n=5)$ ASIA C-E $(n=3)$ ASIA D-E $(n=5)$ & 28.4 & 95 \\
Group II & ASIA A-B $(n=3)$ ASIA A-C $(n=3)$ ASIA B-C $(n=4)$ ASIA B-D $(n=3)$ & & 58 \\
& ASIA C-D $(n=6)$ ASIA C-E $(n=2)$ ASIA D-E $(n=8)$ & 33.3 & 87 \\
\hline
\end{tabular}

ASIA: American spinal injury association motor index score. 
imental studies have demonstrated that methylprednisolone reduces inflammation, attenuates the production of free radicals, and decreases lipid peroxidation. Additionally, methylprednisolone increases $\mathrm{Na}+/ \mathrm{K}+$-ATPase activity and promote local blood supply and perfusion. ${ }^{[20-23]}$

Methylprednisolone shows some neuroprotective effects due to its antioxidant properties. Methylprednisolone decreases tumor necrosis alpha synthesis, increases blood flow to the spinal cord, decreases calcium accumulation, decreases posttraumatic axonal injury and lipid peroxidation. ${ }^{[2]}$ We should note that although methylprednisolone has some beneficial effects, it also has significant side effects, ${ }^{[25]}$ particularly high dose methylprednisolone after $\mathrm{SCl}$ increases the risk of wound infection, pneumonia, sepsis, gastrointestinal hemorrhage, pulmonary injury and may lead to even death. ${ }^{[25,26]}$

Among the clinical trials that aimed to evaluate the NASCIS II and NASCIS III protocols, Bracken et al. ${ }^{[2-5]}$ reported that methylprednisolone treatment improved neurological function but increased the probability of infection. However, other clinical studies indicated that the NASCIS II protocol did not produce any beneficial effects on neurological function. ${ }^{[27-29]}$

In our clinic, we routinely started methylprednisolone treatment to $\mathrm{SCl}$ patients according to the NASCIS II protoco|[ ${ }^{[2]}$ until 20II, but then we gave up this medication after novel findings that indicated severe side effects of methylprednisolone treatment. ${ }^{[15]}$

In this study, we evaluate the potential effects of intravenous methylprednisolone treatment on the neurological outcome of $\mathrm{SCl}$ patients which have thoracolumbar junction spine fractures. According to our results, steroids have no significant beneficial effects on the neurological outcome of $\mathrm{SCl}$ patients but have significant side effects and leads to increased complication rates.

The primary limitation of the present study is its retrospective nature. However, the findings obtained in this study may contribute to the awareness about the significant side effects of steroids in this patient group.

\section{Conclusion}

Steroids have no significant beneficial effects on the neurological outcome of $\mathrm{SCl}$ patients but have significant side effects and lead to increased complication rates.

\section{Conflict of interest: None declared.}

\section{REFERENCES}

1. Dusart I, Schwab ME. Secondary cell death and the inflammatory reaction after dorsal hemisection of the rat spinal cord. Eur J Neurosci 1994;6:712-24. [CrossRef]
2. Bracken MB, Shepard MJ, Collins WF, Holford TR, Young W, Baskin DS, et al. A randomized, controlled trial of methylprednisolone or naloxone in the treatment of acute spinal-cord injury. Results of the Second National Acute Spinal Cord Injury Study. N Engl J Med 1990;322:140511. [CrossRef]

3. Bracken MB, Shepard MJ, Collins WF Jr, Holford TR, Baskin DS, Eisenberg HM, et al. Methylprednisolone or naloxone treatment after acute spinal cord injury: 1-year follow-up data. Results of the second National Acute Spinal Cord Injury Study. J Neurosurg 1992;76:23-31. [CrossRef]

4. Bracken MB, Shepard MJ, Holford TR, Leo-Summers L, Aldrich EF, Fazl M, et al. Administration of methylprednisolone for 24 or 48 hours or tirilazad mesylate for 48 hours in the treatment of acute spinal cord injury. Results of the Third National Acute Spinal Cord Injury Randomized Controlled Trial. National Acute Spinal Cord Injury Study. JAMA 1997;277:1597-604. [CrossRef]

5. Bracken MB, Shepard MJ, Holford TR, Leo-Summers L, Aldrich EF, Fazl M, et al. Methylprednisolone or tirilazad mesylate administration after acute spinal cord injury: 1-year follow up. Results of the third $\mathrm{Na}$ tional Acute Spinal Cord Injury randomized controlled trial. J Neurosurg 1998;89:699-706. [CrossRef]

6. Bydon M, Lin J, Macki M, Gokaslan ZL, Bydon A. The current role of steroids in acute spinal cord injury. World Neurosurg 2014;82:848-54.

7. Hurlbert RJ, Hadley MN, Walters BC, Aarabi B, Dhall SS, Gelb DE, et al. Pharmacological therapy for acute spinal cord injury. Neurosurgery 2013;72:93-105. [CrossRef]

8. Merola A, O'Brien MF, Castro BA, Smith DA, Eule JM, Lowe TG, et al. Histologic characterization of acute spinal cord injury treated with intravenous methylprednisolone.J Orthop Trauma 2002;16:155-61. [CrossRef]

9. Rabchevsky AG, Fugaccia I, Sullivan PG, Blades DA, Scheff SW. Efficacy of methylprednisolone therapy for the injured rat spinal cord. J Neurosci Res 2002;68:7-18. [CrossRef]

10. Suberviola B, González-Castro A, Llorca J, Ortiz-Melón F, Miñambres E. Early complications of high-dose methylprednisolone in acute spinal cord injury patients. Injury 2008;39:748-52. [CrossRef]

11. Ito Y, Sugimoto Y, Tomioka M, Kai N, Tanaka M. Does high dose methylprednisolone sodium succinate really improveneurological status in patient with acute cervical cord injury?: a prospectivestudy about neurological recovery and early complications. Spine (Phila Pa 1976) 2009;34:2121-4. [CrossRef]

12. Rowland JW, Hawryluk GW, Kwon B, Fehlings MG. Current status of acute spinal cord injury pathophysiology and emerging therapies: promise on the horizon. Neurosurg Focus 2008;25:E2. [CrossRef]

13. Tator $\mathrm{CH}$. Update on the pathophysiology and pathology of acute spinal cord injury. Brain Pathol 1995;5:407-13. [CrossRef]

14. Park SJ, Oh IS, Kwon JY, Ha KY. The effect of irradiation and methylprednisolone in spinal cord injured rats. Spine (Phila Pa 1976) 2011;36:434-40. [CrossRef]

15. Taoka Y, Okajima K. Role of leukocytes in spinal cord injury in rats. J Neurotrauma 2000;17:219-29. [CrossRef]

16. Tator $\mathrm{CH}$, Fehlings MG. Review of the secondary injury theory of acute spinal cord trauma with emphasis on vascular mechanisms. J Neurosurg 1991;75:15-26. [CrossRef]

17. Bracken MB, Collins WF, Freeman DF, Shepard MJ, Wagner FW, Silten RM, et al. Efficacy of methylprednisolone in acute spinal cord injury. JAMA 1984;251:45-52. [CrossRef]

18. Kwon BK, Okon E, Hillyer J, Mann C, Baptiste D, Weaver LC, et al. A systematic review of non-invasive pharmacologic neuroprotective treatments for acute spinal cord injury. J Neurotrauma 2011;28:1545-88. [CrossRef]

19. Olsson Y, Sharma HS, Nyberg F, Westman J. The opioid receptor antag- 
onist naloxone influences the pathophysiology of spinal cord injury. Prog Brain Res 1995;104:381-99. [CrossRef]

20. Braughler JM, Hall ED. Correlation of methylprednisolone levels in cat spinal cord with its effects on $(\mathrm{Na}++\mathrm{K}+)$-ATPase, lipid peroxidation, and alpha motor neuron function. J Neurosurg 1982;56:838-44. [CrossRef]

21. Braughler JM, Hall ED. Lactate and pyruvate metabolism in injured cat spinal cord before and after a single large intravenous dose of methylprednisolone. J Neurosurg 1983;59:256-61. [CrossRef]

22. Hall ED. Neuroprotective actions of glucocorticoid and nonglucocorticoid steroids in acute neuronal injury. Cell Mol Neurobiol 1993;13:41532. [CrossRef]

23. Jones TB, McDaniel EE, Popovich PG. Inflammatory-mediated injury and repair in the traumatically injured spinal cord. Curr Pharm Des 2005;11:1223-36. [CrossRef]

24. Hall ED, Springer JE. Neuroprotection and acute spinal cord injury: a reappraisal. NeuroRx 2004;1:80-100. [CrossRef]

25. Hurlbert RJ. The role of steroids in acute spinal cord injury: an evidencebased analysis. Spine (Phila Pa 1976) 2001;26:S39-46. [CrossRef]

26. Khan MF, Burks SS, Al-Khayat H, Levi AD. The effect of steroids on the incidence of gastrointestinal hemorrhage after spinal cord injury: a casecontrolled study. Spinal Cord 2014;52:58-60. [CrossRef]

27. Felleiter P, Müller N, Schumann F, Felix O, Lierz P. Changes in the use of the methylprednisolone protocol for traumatic spinal cord injury in Switzerland. Spine (Phila Pa 1976) 2012;37:953-6. [CrossRef]

28. Pointillart V, Petitjean ME, Wiart L, Vital JM, Lassié P, Thicoipé M, et al. Pharmacological therapy of spinal cord injury during the acute phase. Spinal Cord 2000;38:71-6. [CrossRef]

29. Short DJ, El Masry WS, Jones PW. High dose methylprednisolone in the management of acute spinal cord injury - a systematic review from a clinical perspective. Spinal Cord 2000;38:273-86. [CrossRef]

\section{ORIJIINAL ÇALIŞMA - ÖZET}

\section{Travmatik torakolomber bileşke yaralanmalı hastalarda steroidin nörolojik sonuçlar üzerine etkisi \\ Dr. Mustafa Kemal İlik, ${ }^{1}$ Dr. Fatih Keskin, ${ }^{2}$ Dr. Fatih Erdi, ${ }^{2}$ Dr. Bülent Kaya, ${ }^{2}$ Dr. Yaşar Karataş, ${ }^{2}$ Dr. Erdal Kalkan ${ }^{2}$}

${ }^{1}$ Farabi Hastanesi, Nöroşirürji Kliniği, Konya

${ }^{2}$ Necmettin Erbakan Üniversitesi Meram Tıp Fakültesi, Nöroşirürji Anabilim Dalı, Konya

AMAÇ: Bu çalısmada metilprednizolonun torakolomber bileşke (TIO-LI) kırıkları ile beraber spinal kord yaralanması olan hastalarda nörolojik sonuçlarına etkisi değerlendirildi.

GEREÇ VE YÖNTEM: Eylül 2008-Ocak 2015 ayları arasında torakolomber bileşke kırı̆ı̆ı nedeniyle ameliyat ettiğimiz I 82 hastanın bilgileri geriye dönük olarak değerlendirildi. Hastalar iki gruba ayrıldı. Grup I; erken cerrahi ile beraber metilprednizolon tedavisi uygulanan grup iken, Grup 2; metilprednizolon tedavisi verilmeyen sadece erken cerrahi uygulanan gruptu. Hastaların ilk başvuruda ve son muayene kayıtlarına göre motor indeks skorları Amerikan Spinal Yaralanma Birliği (ASIA) skalasına göre değerlendirildi. Sonuçlar istatistiki olarak karşılaştırıldı.

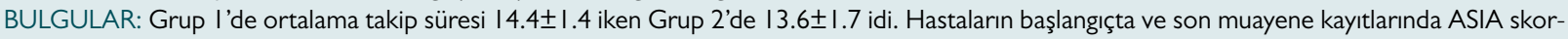
ları benzerdi ( $p>0.05)$. Komplikasyon oranı ise Grup I'de belirgin şekilde yüksekti $(p<0.05)$.

TARTIŞMA: Bulgularımıza göre spinal kord yaralanması olan hastalarda steroidin nörolojik sonuçlar üzerine belirgin faydalı etkisi yoktur ve yan etkisiyle komplikasyon oranını arttırmaktadır.

Anahtar sözcükler: Metilprednizolon; spinal kord yaralanması; tedavi; torakolomber bileşke.

Ulus Travma Acil Cerrahi Derg 2019;25(5):484-488 doi: 10.5505/tjtes.2018.8672। 